Original Research Paper

\title{
Current Stage in the Field of Mechanisms with Gears and Rods
}

\author{
${ }^{1}$ Relly Victoria Virgil Petrescu, ${ }^{2}$ Raffaella Aversa, \\ ${ }^{2}$ Antonio Apicella, ${ }^{3}$ Samuel Kozaitis, \\ ${ }^{4}$ Taher Abu-Lebdeh and ${ }^{1}$ Florian Ion Tiberiu Petrescu

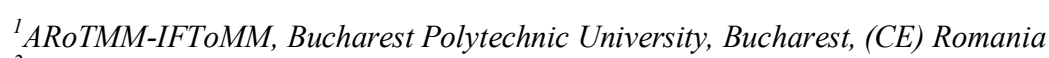 \\ ${ }^{2}$ Advanced Material Lab, Department of Architecture and Industrial Design, \\ Second University of Naples, 81031 Aversa (CE) Italy \\ ${ }^{3}$ Florida Institute of Technology, USA \\ ${ }^{4}$ North Carolina A and T State University, USA
}

Article history

Received: 30-11-2017

Revised: 07-12-2017

Accepted: 12-12-2017

Corresponding Author: Florian Ion Tiberiu Petrescu ARoTMM-IFToMM, Bucharest Polytechnic University, Bucharest, (CE) Romania Email: scipub02@gmail.com

\begin{abstract}
The development and diversification of machines and mechanisms with applications in all fields require new scientific researches for the systematization and improvement of existing mechanical systems by creating new mechanisms adapted to modern requirements, which involve increasingly complex topological structures. The modern industry, the practice of designing and building machinery is increasingly based on the results of scientific and applied research. Each industrial achievement has backed theoretical and experimental computer-assisted research, which solves increasingly complex problems with advanced computing programs using an increasingly specialized software. The robotization of technological processes determines and influences the emergence of new industries, applications under special environmental conditions, the approach of new types of technological operations, manipulation of objects in the alien space, teleoperators in the top disciplines like medicine, robots covering a whole field Greater service provision in our modern, computerized society. In this context, the present paper attempts to make a scientific and technical contribution to the kinematic analysis and geometric - kinematic synthesis of gears and gears, both as plane and spatial structures. By definition, these complex mechanisms are composed of bars and lever mechanisms (gears and racks). A remarkable problem with the use of conical gears is the spherical coupling design through threeaxis spherical gear mechanisms. This modeling is extremely useful in the construction and kinematics of robots, especially the orientation mechanisms, which explains the particular interest in the use of gears and gears. The cinematic study methods of complex gears with bars and gears are particularly diverse, but a unitary method allows the adaptation and use of more efficient analytical and numerical resolution algorithms. The beginning of the use of gears and gears should be sought in ancient Egypt at least a thousand years before Christ. Here, for the first time, spur gears were used for crop irrigation and worm gears for cotton processing.
\end{abstract}

Keywords: Mechanism, Applied Computing, Algorithm, Machines and Mechanisms, Gears and Rods

\section{Introduction}

The development and diversification of machines and mechanisms with applications in all fields requires new scientific researches for the systematization and improvement of existing mechanical systems by creating new mechanisms adapted to modern requirements, which involve increasingly complex topological structures. 
The modern industry, the practice of designing and building machinery is increasingly based on the results of scientific and applied research.

Each industrial achievement has backed theoretical and experimental computer-assisted research, which solves increasingly complex problems with advanced computing programs using increasingly specialized software.

The robotization of technological processes determines and influences the emergence of new industries, applications under special environmental conditions, the approach of new types of technological operations, manipulation of objects in the alien space, teleoperators in the top disciplines like medicine, robots covering a whole field Greater service provision in our modern, computerized society.

In this context, the present paper attempts to make a scientific and technical contribution to the kinematic analysis and geometric - kinematic synthesis of gears and gears, both as plane and spatial structures.

By definition, these complex mechanisms are composed of bars and lever mechanisms (gears and racks).

Only mechanisms with rigid kinematic elements were considered, both the bars and the toothed wheels being considered undeformable.

During the elaboration of this paper, the following requirements were considered:

- $\quad$ Performing a unitary work on documenting and personal scientific contributions

- The synthetic way of presenting the different aspects analyzed

- Highlighting the outstanding achievements of researchers and mechanics specialists

- The creation of a high-level scientific work, but with the possibility of being traced easily by specialists

- To formulate conclusions to fix what is essential and to generate new ideas

A remarkable problem with the use of conical gears is the spherical coupling design through three-axis spherical gear mechanisms.

This modeling is extremely useful in the construction and kinematics of robots, especially the orientation mechanisms, which explains the particular interest in the use of gears and gears.

The cinematic study methods of complex gears with bars and gears are particularly diverse, but a unitary method allows the adaptation and use of more efficient analytical and numerical resolution algorithms.

The beginning of the use of gears and gears should be sought in ancient Egypt at least a thousand years before Christ.

Here, for the first time, spur gears were used for crop irrigation and worm gears for cotton processing.
230 years BC, in the city of Alexandria in Egypt, a multi-lever wheel was used and a rack gear.

Also, planetary gears with satellite gears have been used since the time of the $100-80 \mathrm{BC}$, to an ancient Greek astrolab.

This ingenious mechanism displays the movement of the sun and the moon with the help of dozens of gears of different sizes, the movement of which came from a single cinematic input element.

The transmission of gear with gears has seen substantial progress since $1300 \mathrm{AD}$, when the Italian master Giovani da Dondi made an astronomical horology, composed of internal gears and elliptical gears.

In the fifteenth century, Leonardo da Vinci laid the foundations for modern cinematics and dynamics, stating, among other things, the principle of superposition of independent movements.

This principle of the summation of independent movements will be applied successfully, in the present paper, to the analysis and kinematic synthesis of the complex mechanisms with multi mobile gears and bars.

The first gear adjustable gears were used in 1769 by Cugnot to equip the first vehicle propelled by a steam engine.

Between 1778 and 1784, J. Watt designed and built a new steam machine (Dudita, 1989; Watt steam engine, From Wikipedia) with a double-acting piston, in which the alternative translational movement of the piston is transformed into a continuous and uniform rotation of a steering wheel. In order to transform the oscillating rotation motion of the rocker in a continuous rotary motion of the crank, the Watt has created several distinct mechanisms, including the planetary gear with cylindrical gears.

The Englishman E. Cartwright created and patented in 1800 a rectilinear guiding mechanism with symmetrically placed bars and gears for the purpose of transforming the movement of the piston (steam driven) into rotation of the steering wheel.

During the same period, at the beginning of the 19th century, another Englishman, J. White, discovered that the rectilinear guidance of a point can be done with a planetary cylindrical mechanism with an internal gear, which generates a particular degenerated right hippoccillus.

At the end of the 19th century, in 1886, German Carl Benz made the first three-wheeled motor propelled by a thermal engine with a horizontally placed cylinder.

Since the flywheel has a vertical spindle, a conical gear has been used to convey the engine torque from the flywheel to the propulsion wheels.

In the twentieth century, with the modern industrial development, textile and metallurgical machines, packaging machines and, more recently, industrial manipulators and robots, the transmission of the rotation between shafts with varying axle spacing appears necessary. 
Often, it is required that the uninterrupted and uniform rotation of the drive shaft will result in reversible rotation of the driven shaft, movement with stops during the given limit, motion in the pilgrim step, etc.

In a series of machines and robot manipulators, it is necessary to obtain complex trajectories of some points of the elements, which can't be obtained with the help of ordinary bars.

Such technical requirements can be satisfied if gears with gears and gears are used.

For this purpose, mechanisms can be constructed in which bar systems and toothed wheel systems are (in parallel, overlapped) and the elements of the bar mechanism bear on their sprocket wheels axes.

There are also complex gears with bars and gears, in which the gears are parts of the general structural scheme.

As examples of such combined mechanisms, several kinematic schemes of gears and gears can be observed, presented by Kojevnikov (1969), (AUTORENKOLLEKTIV, 1968), Şaskin (1963; 1971), Maros (1958), Rehwald and Luck, 2000; 2001), Antonescu (1993; Antonescu and Mitrache, 1989).

The main problems with plane and spatial gears and gears refer to kinematic analysis and geometrickinematic synthesis under certain conditions imposed by technological processes, Bruja and Dima (2011), Buda and Mateucă, (1989), Luck and Modler (1995), Niemeyer (2000), Tutunaru (1969), Popescu (1977), Braune (2000), Dudita (1989), Lichtenheldt (1995), Lederer (1993), Lin (1999), Modler and Wadewitz (1998; 2001; Modler, 1979), Neumann (1979; 2001), Stoica (1977), Petrescu and Petrescu (2011c; 2011d; Petrescu, 2012d; 2012e); (Petrescu, 2016; Petrescu et al., 2017a; 2017b; 2017c; 2017d; 2017e; 2017f; 2017g; 2017h; 2017i; 2017j; 2017k; 2017l; 2017m; 2017n; 2017o; 2017p; 2017q; Aversa et al., 2017a; 2017b; 2017c; 2017d; 2017e; 2016a; 2016b; 2016c; 2016d; 2016e; 2016f; 2016g; 2016h; 2016i; 2016j; 2016k; 2016l; 2016m; 2016n; 2016o; Mirsayar et al., 2017; Petrescu and Petrescu, 2016a; 2016b; 2016c; 2013a; 2013b; 2013c; 2013d, 2012a; 2012b; 2012c; 2012d, 2011a; 2011b; Petrescu, 2012a; 2012b; 2012c, 2009; Petrescu and Calautit, 2016a; 2016b; Petrescu et al., 2016a; 2016b).

\section{Materials and Methods}

\section{Research on Cinematic Analysis of Rods and Gears Mechanisms}

The most representative schools of mechanics that have developed and initiated theoretical and practical scientific research in the field of rods and gears were the German school (K. Hoecken, W. Jahr, P. Knechtel, K. Hain, W. Mayer zur Cappellen, W. Rath, O. Tolle, J. Volmer, R. Neumann, W. Rehwald, K. Luck, KH Modler) and Russian (SO Dobrogurski, II Artobolevski, SN Kojevnikov, LB Maisiuk, SA Cerkudinov, AS Saskin).
In Fig. 1a is shown (Dudita, 1989; Petrescu and Petrescu, 2011c; 2011d; Petrescu, 2012d; 2012e) the mechanism with geared wheel driven $z_{3}$ whose motion is transmitted from geared wheel $z_{2}$ on the cradle c of the quadrilateral mechanism. Wheel $z_{2}$ engages with wheel $z_{1}$ which rotates with respect to an eccentric axis.

Depending on the correlated dimensions of the bar elements and the number of teeth of the $z_{3}$ geared wheel to the output shaft, the rotation obtained may be continuous (uninterrupted) with a degree of unevenness, stop motion, partial forward movement (pilgrimage step) Fig. 1b.

In Fig. 2, there are shown a few schematic of rods and gears constructed on the basis of the four-tiered bar mechanism, whose driven toothed wheels rotate around the fixed axis of the rocker and the drive is made from the crank a.

Various combinations of bar mechanisms and gears with circular and non-circular wheels can be built in a very large number, but a small number of all practical variants are used.

In connection with the above we consider only 2 types of gears and gears, namely: The mechanisms for transmitting the rotation between shafts with the variable distance between the axes and the mechanisms used to obtain the complex-looking trajectories and the transformation of the movement.

From the point of view of the structural elements, all wheel and ring gears with circular wheels can be regarded as series chains with the variable configuration of the center line, variation which determines the position of the elements, of the axes of the non-essential gears.

It may be that the transmission of the movement from the toothed wheel of the chain to another toothed wheel element of the neighboring member is accomplished only if the toothed wheel or toothed wheel of the group has an axis superimposed with the axis of the joint formed by these bars.

In the general case, the beam and gear mechanism can be considered to have 2 or more mobility.

As an example of multi mobile mechanism with bars and gears, the kinematic scheme of Fig. 3a is considered; this mechanism has 3 mobilities.

Thus, the angular velocity of any of the wheels can be determined if the angular speeds of bars $a$ and $b$ and one of the gears are required.

The number of mobilities and therefore the number of leading elements can be reduced if the elements are joined together. For example, if the wheel 1 is connected to the base and the wheel 2 with the element $\mathrm{b}$, the mono mobile mechanism (Fig. $3 \mathrm{~b}$ ) is obtained, in which the wheels 2 and 3 do not rotate with respect to bar $\mathrm{b}$, but the point $\mathrm{C}$ describes what Called epicycloid elongated. Such a mechanism is also called the "dyad train" (Maros, 1958; Modler and Wadewitz, 2001; Manolescu, 1968; Margine, 1999). 


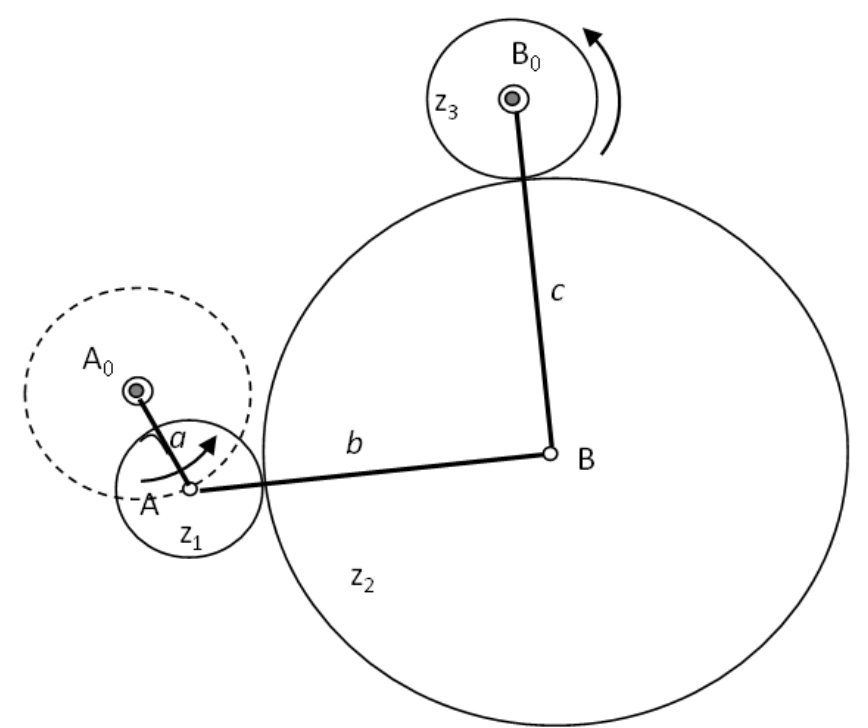

(a)

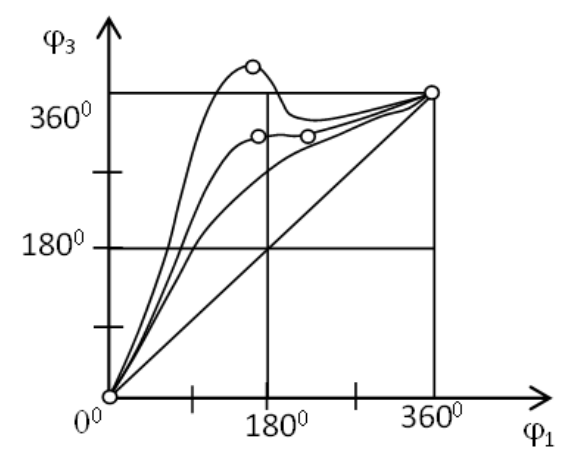

(b)

Fig. 1: The mechanism with geared wheel

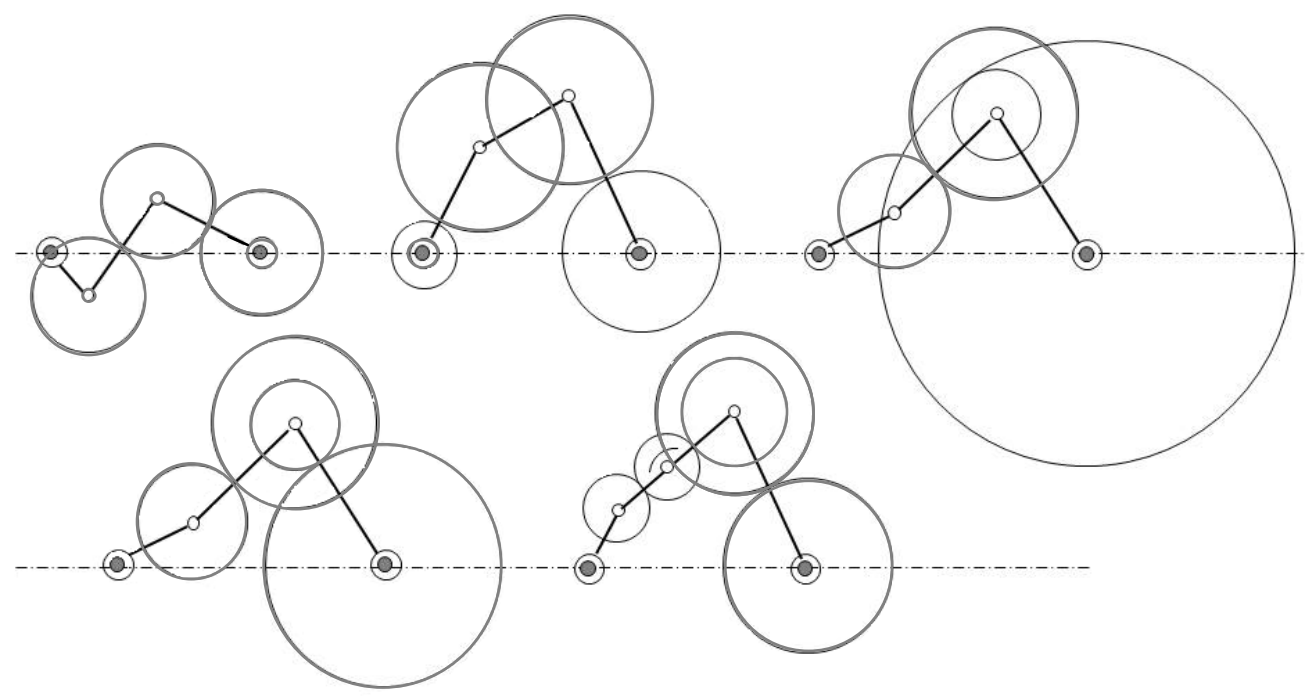

Fig. 2: Schematic of rods and gears constructed on the basis of the four-tiered bar mechanism

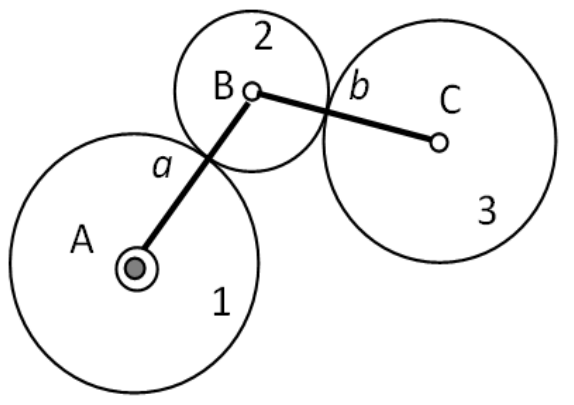

(a)

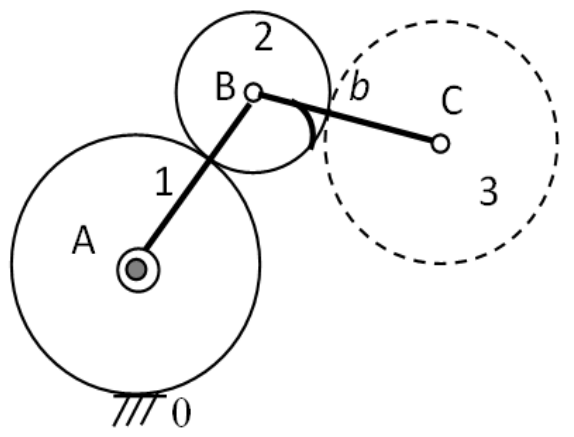

(b)

Fig. 3: An example of multi mobile mechanism with bars and gears 


\section{Results}

The movement of the point B (Fig. 3a) can be controlled by conditioning the displacement of point $\mathrm{B}$, for example (Fig. 4) on the circular arc with the BD radius and the fixed $\mathrm{D}$ center.

The resulting mechanism has two mobilities; in its movement the driven wheel 4 depends on the angular velocity of one of the toothed wheels of the series chain wheel and the angular velocity of one of the bars of the articulated quadrilateral mechanism.

This quadrilateral mechanism can be accepted as a basic mechanism. This case, starting from its kinematic relationship, can be extended to different particular cases.

It is a question of determining the angular velocity of one of the sprocket wheels, for example, $z_{3}$, depending on $\omega_{1}$ and $\omega_{a}$ date.

The mechanism with bars and gears represented in Fig. 4 can be considered as two differential mechanisms with known movements of the known bars a and $c$ at which the angular speeds of the wheels 2 and 3 are in a determined ratio.

If the link between the wheels 2 and 3 is assumed to be interrupted, then the following can be written:

$i_{12}^{a}=\frac{\omega_{1}-\omega_{a}}{\omega_{2}-\omega_{a}} ; i_{34}^{c}=\frac{\omega_{3}-\omega_{c}}{\omega_{4}-\omega_{c}}$

where the transmission ratios $i_{12}^{a}$ and $i_{34}^{c}$ are calculated in the case of the fixed axle outer gear:

$i_{12}^{a}=-\frac{z_{2}}{z_{1}} ; i_{34}^{c}=-\frac{z_{4}}{z_{3^{\prime}}}$

From formulas (1), the angular speeds of wheels 2 and 4 are explained:

$\omega_{2}=\omega_{1} \cdot i_{21}^{a}+\omega_{a}\left(1-i_{21}^{a}\right)$

$\omega_{4}=\omega_{3} \cdot i_{43}^{c}+\omega_{c}\left(1-i_{43}^{c}\right)$

The transmission ratio of gear units 2,3 is written in relation to b:

$i_{23}^{b}=\frac{\omega_{2}-\omega_{b}}{\omega_{3}-\omega_{b}}=-\frac{z_{3}}{z_{2}}$

From formula (5) it is deduced:

$\omega_{3}=\omega_{2} \cdot i_{32}^{b}+\omega_{b}\left(1-i_{32}^{b}\right)$

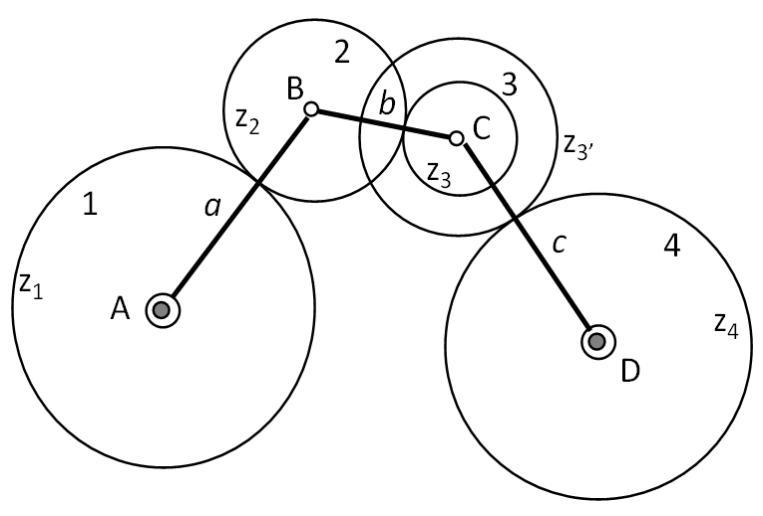

Fig. 4: Two differential mechanisms with known movements

By observing formulas (3) and (6) of formula (4), the angular velocity of the wheel 4 is obtained according to the angular speed of the wheel 1 and the three bars $a, b$ and $c$ :

$$
\begin{aligned}
& \omega_{4}=\omega_{1} \cdot i_{21}^{a} \cdot i_{32}^{b} \cdot i_{43}^{c}+\omega_{a} \cdot\left(1-i_{21}^{a}\right) \cdot i_{32}^{b} \cdot i_{43}^{c} \\
& +\omega_{b} \cdot\left(1-i_{32}^{b}\right) \cdot i_{43}^{c}+\omega_{c}\left(1-i_{43}^{c}\right)
\end{aligned}
$$

In this Equation $7 \omega_{b}$ and $\omega_{c}$ are functions of $\omega_{a}$ and can be determined as transmission functions between the bars of the quadrilateral mechanism:

$\omega_{b}=\omega_{a} \cdot i_{b a} ; \omega_{c}=\omega_{a} \cdot i_{c a}$

This is why $\omega_{4}$ it is a function of two independent variables $\omega_{4}$ and $\omega_{a}$.

For all the gear and gear mechanism schemes of Fig. 2 , in which the wheel 2 is locked with the arm a, the required condition is $\omega_{2}=\omega_{a}$.

In these cases it results $\omega_{1}=\omega_{a}$ from Equation 3, which means that the $z_{1}$ wheel is locked with the crank a and formula (7) becomes:

$\omega_{4}=\omega_{a} \cdot i_{32}^{b} \cdot i_{43}^{c}+\omega_{b} \cdot\left(1-i_{32}^{b}\right) \cdot i_{43}^{c}$
$+\omega_{c}\left(1-i_{43}^{c}\right)$

If the wheels 2 and 3 are blocked on $b$, then $\omega_{2}=\omega_{3}=$ $\omega_{a}$, so that from Equation 3 and 4 the relations are deduced:

$$
\begin{aligned}
& \omega_{1}=\omega_{b} \cdot i_{12}^{a}+\omega_{a} \cdot\left(1-i_{12}^{a}\right) \\
& \omega_{4}=\omega_{b} \cdot i_{43}^{c}+\omega_{c} \cdot\left(1-i_{43}^{c}\right)
\end{aligned}
$$

Formula (10) can be used to calculate the angular velocity of the driven element (Dudita, 1989) of the Watt engine mechanism (Fig. 5), in which the wheels are missing $z_{3}$ and $z_{4}$ and $\omega_{c}=0$. 


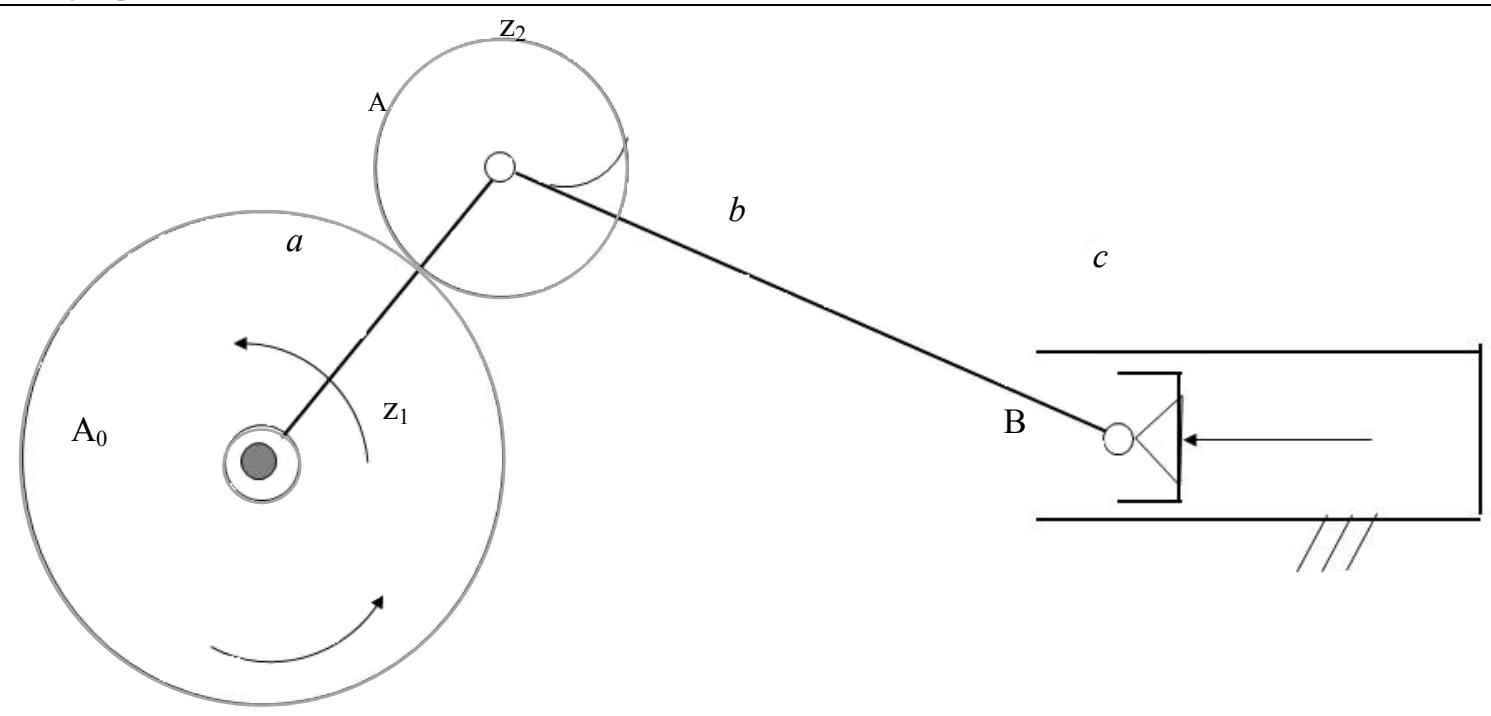

Fig. 5: Watt engine mechanism

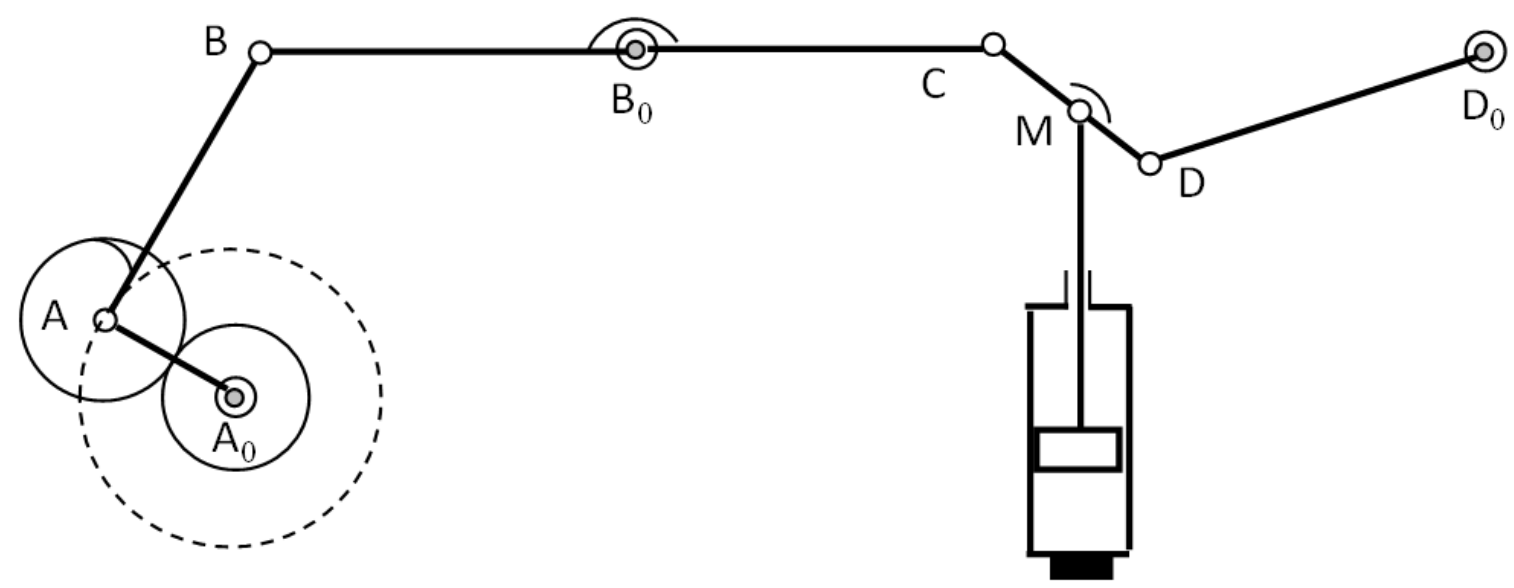

Fig. 6: Watt imagined a new mechanism, combining the crankshaft mechanism with a planetary gear with two gears

It is worth mentioning that $\mathrm{J}$. Watt used such a steam machine scheme that he patented in 1784 (Dudita, 1989).

Following the transformation of the oscillating rotation movement in continuous rotation, J. Watt imagined a new mechanism, combining the crankshaft mechanism with a planetary gear with two gears (Fig. 6).

Note that the translational movement of the piston is approximately maintained by the point $\mathrm{M}$ on the bar of a rocker-rocker articulated, which had already been invented by J. Watt.

The translational movement of the piston in the vertical cylinder (Fig. 6) first turns into oscillating rotation of the $\mathrm{BB}_{0} \mathrm{C}$, after which the balancing motion is transformed into a continuous rotation motion by means of a planetary gear with a central wheel and a satellite wheel Solidarity with white AB.

The Englishman E. Cartwright invented in 1800 (Dudita, 1989; Kojevnikov, 1969) a guiding mechanism with articulated bars and two symmetrically arranged toothed wheels (Fig. 7a) for the purpose of transforming the reciprocating movement of the piston (driven by steam) in motion Rotation of the steering wheel.

The piston rod 1 is articulated with the bar 2 at the point $\mathrm{E}$, which is located on the mediator of the $\mathrm{CD}$ segment. The trajectories of the points $\mathrm{C}$ and $\mathrm{D}$ are rectilinear parallel to the piston $\operatorname{rod} 1$. The $\mathrm{A}_{0} \mathrm{~A}$ and $\mathrm{B}_{0} \mathrm{~B}$ manikins are mounted integrally on each respective wheel gear 5 and 6 in a symmetrical position relative to the vertical point $E$, which provides for equal rotation angles.

From the analysis of the equivalent kinematic scheme (Fig. 7b), which specifies the leading element 1, the symmetry is even more emphasized.

The topological structure of this mechanism identifies a passive (zero mobility) cinematic chain whose hexagonal configuration is (Antonescu, 2003). 


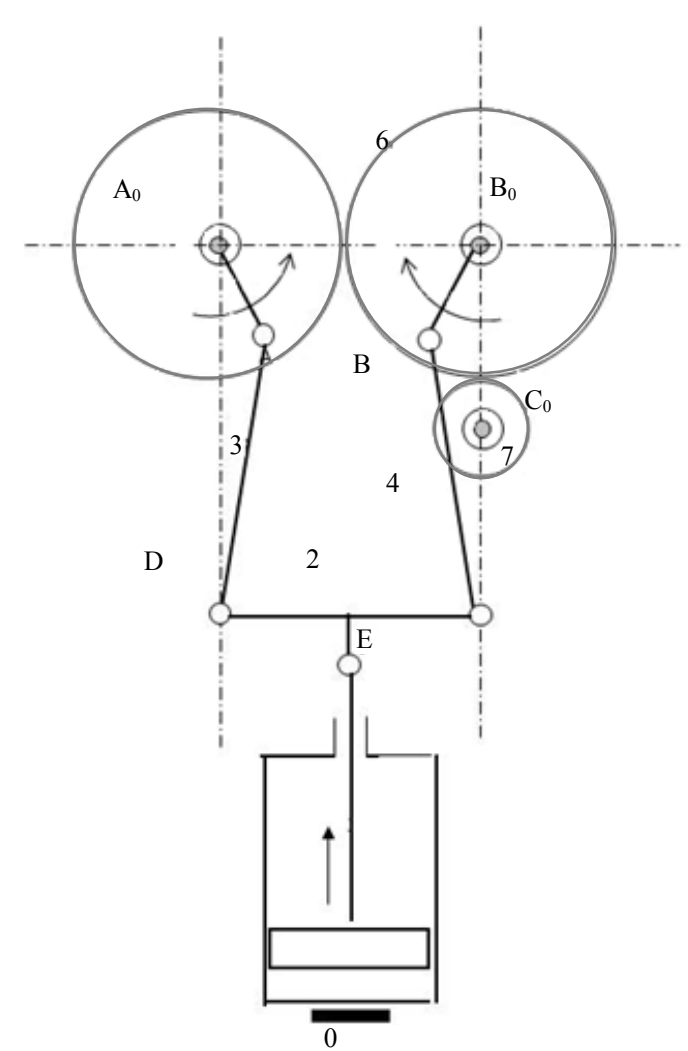

(a)

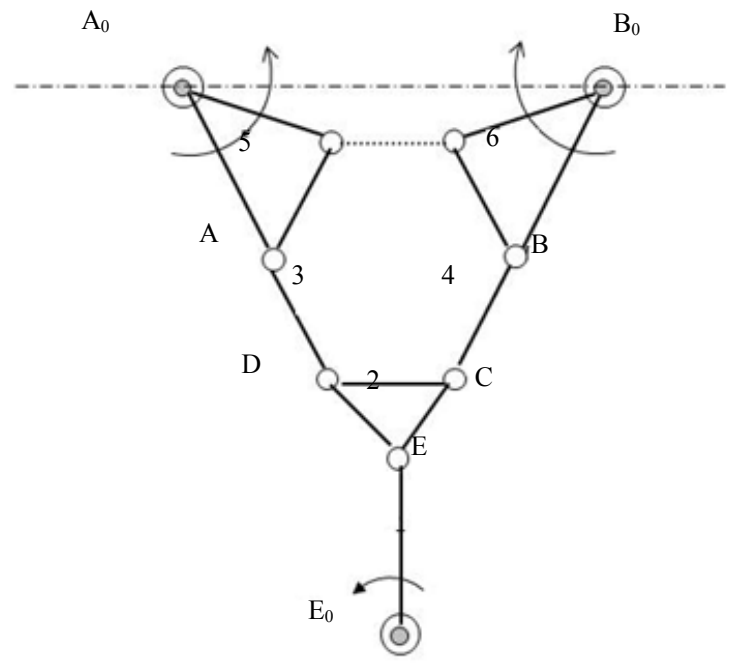

(b)

Fig. 7: A guiding mechanism with articulated bars and two symmetrically arranged toothed wheels

\section{Discussion}

The development and diversification of machines and mechanisms with applications in all fields require new scientific researches for the systematization and improvement of existing mechanical systems by creating new mechanisms adapted to modern requirements, which involve increasingly complex topological structures.

The modern industry, the practice of designing and building machinery is increasingly based on the results of scientific and applied research. Each industrial achievement has backed theoretical and experimental computer-assisted research, which solves increasingly complex problems with advanced computing programs using an increasingly specialized software.

The robotization of technological processes determines and influences the emergence of new industries, applications under special environmental conditions, the approach of new types of technological operations, manipulation of objects in the alien space, teleoperators in the top disciplines like medicine, robots covering a whole field Greater service provision in our modern, computerized society.

In this context, the present paper attempts to make a scientific and technical contribution to the kinematic analysis and geometric - kinematic synthesis of gears and gears, both as plane and spatial structures. By definition, these complex mechanisms are composed of bars and lever mechanisms (gears and racks).

A remarkable problem with the use of conical gears is the spherical coupling design through three-axis spherical gear mechanisms. This modeling is extremely useful in the construction and kinematics of robots, especially the orientation mechanisms, which explains the particular interest in the use of gears and gears.

The cinematic study methods of complex gears with bars and gears are particularly diverse, but a unitary method allows the adaptation and use of more efficient analytical and numerical resolution algorithms.

The beginning of the use of gears and gears should be sought in ancient Egypt at least a thousand years before Christ. Here, for the first time, spur gears were used for crop irrigation and worm gears for cotton processing.

\section{Conclusion}

Various combinations of bar mechanisms and gears with circular and non-circular wheels can be built in a very large number, but a small number of all practical variants are used.

In connection with the above, we consider only 2 types of gears and gears, namely: The mechanisms for 
transmitting the rotation between shafts with the variable distance between the axes and the mechanisms used to obtain the complex-looking trajectories and the transformation of the movement.

From the point of view of the structural elements, all wheel and ring gears with circular wheels can be regarded as series chains with the variable configuration of the center line, variation which determines the position of the elements, of the axes of the non-essential gears.

It may be that the transmission of the movement from the toothed wheel of the chain to another toothed wheel element of the neighboring member is accomplished only if the toothed wheel or toothed wheel of the group has an axis superimposed with the axis of the joint formed by these bars.

In the general case, the beam and gear mechanism can be considered to have 2 or more mobility.

As an example of multi mobile mechanism with bars and gears, the kinematic scheme of Fig. 3a is considered; this mechanism has 3 mobilities.

Thus, the angular velocity of any of the wheels can be determined if the angular speeds of bars $a$ and $b$ and one of the gears are required.

The number of mobilities and therefore the number of leading elements can be reduced if the elements are joined together.

\section{Acknowledgment}

This text was acknowledged and appreciated by Dr. Veturia CHIROIU Honorific member of Technical Sciences Academy of Romania (ASTR) PhD supervisor in Mechanical Engineering and by Prof. BERTHOLD GRUNWALD, Past Director Mercedes Benz Daimler AG, Germany and Past Head Department of Automotive Engineering from Bucharest Polytechnic University, whom we thank and in this way.

\section{Funding Information}

Research contract: Contract number 27-7-7/1987, beneficiary Central Institute of Machine Construction from Romania (and Romanian National Center for Science and Technology).

All these matters are copyrighted.

Copyrights: 394-qodGnhhtej from 17-02-2010 13:42:18; 396-qkzAdFoDBc from 17-02-2010 17:43:22; 951-cnBGhgsHGr from 26-01-2011 16:29:02; 1375tnzjHFAqGF from 02-09-2011 15:19:23.

\section{Author's Contributions}

All the authors contributed equally to prepare, develop and carry out this manuscript.

\section{Ethics}

This article is original. Authors declare that are not ethical issues that may arise after the publication of this manuscript.

\section{References}

Antonescu, P., 2003. Mecanisms. Printech, Bucureşti.

Antonescu, P., 1993. Synthesis of manipulators. Lito UPB, Bucureşti.

Antonescu, P. and M. Mitrache, 1989. Contributions to the synthesis of the mechanisms used as windscreen wipers. SYROM'89, Bucharest, 4: 23-32.

AUTORENKOLLEKTIV, 1968. Getriebetechnik-VEB. Verlag Technik, Berlin.

Aversa, R., R.V.V. Petrescu, A. Apicella and F.I.T. Petrescu, 2017a. Nano-diamond hybrid materials for structural biomedical application. Am. J. Biochem. Biotechnol., 13: 34-41. DOI: 10.3844/ajbbsp.2017.34.41

Aversa, R., R.V. Petrescu, B. Akash, R.B. Bucinell and J.M. Corchado et al., 2017b. Kinematics and forces to a new model forging manipulator. Am. J. Applied Sci., 14: 60-80. DOI: 10.3844/ajassp.2017.60.80

Aversa, R., R.V. Petrescu, A. Apicella, I.T.F. Petrescu and J.K. Calautit et al., 2017c. Something about the $\mathrm{V}$ engines design. Am. J. Applied Sci., 14: 34-52. DOI: 10.3844/ajassp.2017.34.52

Aversa, R., D. Parcesepe, R.V.V. Petrescu, F. Berto and G. Chen et al., 2017d. Process ability of bulk metallic glasses. Am. J. Applied Sci., 14: 294-301. DOI: 10.3844/ajassp.2017.294.301

Aversa, R., R.V.V. Petrescu, B. Akash, R.B. Bucinell and J.M. Corchado et al., 2017e. Something about the balancing of thermal motors. Am. J. Eng. Applied Sci., 10: 200.217.

DOI: 10.3844/ajeassp.2017.200.217

Aversa, R., F.I.T. Petrescu, R.V. Petrescu and A. Apicella, 2016a. Biomimetic FEA bone modeling for customized hybrid biological prostheses development. Am. J. Applied Sci., 13: 1060-1067. DOI: 10.3844/ajassp.2016.1060.1067

Aversa, R., D. Parcesepe, R.V. Petrescu, G. Chen and F.I.T. Petrescu et al., 2016b. Glassy amorphous metal injection molded induced morphological defects. Am. J. Applied Sci., 13: 1476-1482. DOI: 10.3844/ajassp.2016.1476.1482

Aversa, R., R.V. Petrescu, F.I.T. Petrescu and A. Apicella, 2016c. Smart-factory: Optimization and process control of composite centrifuged pipes. Am. J. Applied Sci., 13: 1330-1341. DOI: 10.3844 /ajassp.2016.1330.1341 
Aversa, R., F. Tamburrino, R.V. Petrescu, F.I.T. Petrescu and M. Artur et al., 2016d. Biomechanically inspired shape memory effect machines driven by muscle like acting NiTi alloys. Am. J. Applied Sci., 13: 1264-1271. DOI: 10.3844/ajassp.2016.1264.1271

Aversa, R., E.M. Buzea, R.V. Petrescu, A. Apicella and M. Neacsa et al., 2016e. Present a mechatronic system having able to determine the concentration of carotenoids. Am. J. Eng. Applied Sci., 9: 1106-1111. DOI: 10.3844/ajeassp.2016.1106.1111

Aversa, R., R.V. Petrescu, R. Sorrentino, F.I.T. Petrescu and A. Apicella, 2016f. Hybrid ceramo-polymeric nanocomposite for biomimetic scaffolds design and preparation. Am. J. Eng. Applied Sci., 9: 1096-1105. DOI: 10.3844/ajeassp.2016.1096.1105

Aversa, R., V. Perrotta, R.V. Petrescu, C. Misiano and F.I.T. Petrescu et al., 2016g. From structural colors to super-hydrophobicity and achromatic transparent protective coatings: Ion plating plasma assisted $\mathrm{TiO}_{2}$ and $\mathrm{SiO}_{2}$ Nano-film deposition. Am. J. Eng. Applied Sci., 9: 1037-1045.

DOI: 10.3844/ajeassp.2016.1037.1045

Aversa, R., R.V. Petrescu, F.I.T. Petrescu and A. Apicella, 2016h. Biomimetic and evolutionary design driven innovation in sustainable products development. Am. J. Eng. Applied Sci., 9: 1027-1036.

DOI: 10.3844/ajeassp.2016.1027.1036

Aversa, R., R.V. Petrescu, A. Apicella and F.I.T. Petrescu, 2016i. Mitochondria are naturally micro robots-a review. Am. J. Eng. Applied Sci., 9: 991-1002. DOI: 10.3844/ajeassp.2016.991.1002

Aversa, R., R.V. Petrescu, A. Apicella and F.I.T. Petrescu, 2016j. We are addicted to vitamins $\mathrm{C}$ and $\mathrm{E}-\mathrm{A}$ review. Am. J. Eng. Applied Sci., 9: 1003-1018.

DOI: 10.3844/ajeassp.2016.1003.1018

Aversa, R., R.V. Petrescu, A. Apicella and F.I.T. Petrescu, 2016k. Physiologic human fluids and swelling behavior of hydrophilic biocompatible hybrid ceramo-polymeric materials. Am. J. Eng. Applied Sci., 9: 962-972.

DOI: 10.3844/ajeassp.2016.962.972

Aversa, R., R.V. Petrescu, A. Apicella and F.I.T. Petrescu, 20161. One can slow down the aging through antioxidants. Am. J. Eng. Applied Sci., 9: 1112-1126. DOI: 10.3844/ajeassp.2016.1112.1126

Aversa, R., R.V. Petrescu, A. Apicella and F.I.T. Petrescu, 2016m. About homeopathy or «Similia similibus curentur $\gg$. Am. J. Eng. Applied Sci., 9: 1164-1172. DOI: 10.3844/ajeassp.2016.1164.1172

Aversa, R., R.V. Petrescu, A. Apicella and F.I.T. Petrescu, 2016n. The basic elements of life's. Am. J. Eng. Applied Sci., 9: 1189-1197.

DOI: 10.3844/ajeassp.2016.1189.1197
Aversa, R., F.I.T. Petrescu, R.V. Petrescu and A. Apicella, 2016o. Flexible stem trabecular prostheses. Am. J. Eng. Applied Sci., 9: 1213-1221. DOI: 10.3844/ajeassp.2016.1213.1221

Braune, R., 2000. Bewegungsdesign: Eine kernkompetenz des getriebe technikers. VDIBerichte Nr. 1567, VDI - Verlag, Dusseldorf.

Bruja, A. and M. Dima, 2001. Synthesis of kinematics of harmonics reducers with rigid front element. Proceedings of the 6th Simpson Nat. of Construction Machinery, (NCM’ 01), pp: 53-59.

Buda, L. and C. Mateucă, 1989. Functional, cinematic and cinetostatic analysis of the lifting mechanism of the passenger carriages. Bucharest.

Dudita, F.L., 1989. Articulated, inventive, cinematic mechanisms. Technical Publishing House, Bucharest.

Kojevnikov, S.N., 1969. Teoria mehanizmov i maşin. Izd. Maşinostroenie, Moskva.

Lederer, P., 1993. Dynamische synthese der ubertragungs-funktion eines Kurvengetriebes. Mech. Mach. Theory, 28: 23-29.

Lichtenheldt, W., 1995. Konstruktionslehre der Getriebe. 1st Edn., Akademie, Verlag Berlin.

Lin, S., 1999. Getriebesynthese nach unscharfen Lagenvorgaben durch Positionierung eines vorbestimmten Getriebes. Fortschritt, Berichte VDI, Reihe 1. Nr. 313, VDI - Verlage, Dusseldorf.

Luck, K. and K.H. Modler, 1995. Getriebetechnik: Analyse, Synthese, Optimierung. 2nd Edn., Springer, New York, ISBN-10: 3540570012, pp: 367.

Manolescu, N.I., 1968. Problems of machine theory and machines. E.D.P., Bucharest.

Margine, A.L., 1999. Contributions to the geometrickinematical and dynamic synthesis of planetary gears with cylindrical gears. PhD Thesis, U.P.B.

Maros, D., 1958. Gear wheel kinematic. Technical Publishing House, Bucharest.

Mirsayar, M.M., V.A. Joneidi, R.V.V. Petrescu, F.I.T. Petrescu and F. Berto, 2017. Extended MTSN criterion for fracture analysis of soda lime glass. Eng. Fracture Mechan., 178: 50-59. DOI: 10.1016/j.engfracmech.2017.04.018

Modler, K.H. and C. Wadewitz, 2001. Synthese von raderkoppelgetriebe als vorschaltgetriebe mit definierter ungleichformigkeit. Wissenschaftliche Zeitschrift, 3: 101-106.

Modler, K.H. and C. Wadewitz, 1998. Trepte, U., Rechnergestutzte Synthese von Raderkoppelgetrieben als Vorschaltgetriebe zur Erzeugung nichtlinearer Antriebsbewegungen. Bericht zum DFG - Vorhaben Mo 537/5 - 1. TU Dresden.

Modler, K.H., 1979. Reakisierung von pilgerschritten durch zweiraderkoppel-getriebe. Dynamik und Getribetechnik. 
Neumann, R., 1979. Einstellbare Raderkoppelgetriebe. Dynamik und Getribe-technik.

Neumann, R., 2001. Dreiraderkoppel: Schrittgetriebe mit zahnradern oder zahnriemen. Bucureşti.

Niemeyer, J., 2000. Das IGM - Getriebelexikon Wissensverarbeitung in der Getriebetechnik mit Hilfe der Internet - Technologie. In: IMG Kolloquium Getriebetechnik 2000, Dittrich, G. (Hrsg.), Forschung and Lehre 1972-2000, Mainz, Aachen, pp: 53-66.

Petrescu, F.I.T., 2016. Valorisation of RomanianRomanian Engineering Tradition. 1st Edn., Create Space Publisher, USA, ISBN-13: 9781537177984.

Petrescu, F.I. and R.V. Petrescu, 2011a. Memories about Flight. 1st Edn., CreateSpace, pp: 652.

Petrescu, F.I. and R.V. Petrescu, 2011b. Mechanical Systems, Serial and Parallel - Course (in romanian). 1st Edn., LULU Publisher, London, UK, ISBN 978-1-4466-0039-9, pp: 124.

Petrescu, F.I.T. and R.V. Petrescu, 2011c. Planetary Trains (Romanian Edition). 1st Edn., CreateSpace, USA, ISBN-13: 978-1468030419, pp: 204.

Petrescu, F.I. and R.V. Petrescu, 2011d. Dynamics of Distribution Mechanisms. 1st Edn., Create Space Publisher, USA, ISBN-13: 978-1-4680-5265-7, pp: 188.

Petrescu, R.V. and F.I.T. Petrescu, 2012a. Northrop. 1st Edn., Books on Demand, ISBN-13: 978-3848209323, pp: 142.

Petrescu, F.I. and R.V. Petrescu, 2012b. New Aircraft II. 1 st Edn., Books on Demand, pp: 138.

Petrescu, F.I. and R.V. Petrescu, 2012c. MecatronicaSisteme Seriale si Paralele. 1st Edn., Create Space Publisher, USA, ISBN-13: 978-1-4750-6613-5, pp: 128.

Petrescu, F.I. and R.V. Petrescu, 2012d. Kinematics of the planar quadrilateral mechanism. Engevista, 14: 345-348. DOI: 10.22409/engevista.v14i3.377

Petrescu, R.V. and F.I. Petrescu, 2013a. Lockheed Martin. 1st Edn., CreateSpace, pp: 114.

Petrescu, R.V. and F.I. Petrescu, 2013b. Northrop. 1st Edn., CreateSpace, pp: 96.

Petrescu, R.V. and F.I. Petrescu, 2013c. The Aviation History or New Aircraft I Color. 1st Edn., CreateSpace, pp: 292.

Petrescu, F.I. and R.V. Petrescu, 2013d. Cinematics of the 3R Dyad. Engevista, 15: 118-124.

Petrescu, F.I. and R.V. Petrescu, 2016a. Parallel moving mechanical systems kinematics. ENGE-VISTA, 18: 455-491.

Petrescu, F.I. and R.V. Petrescu, 2016b. Direct and inverse kinematics to the anthropomorphic robots. ENGEVISTA, 18: 109-124.

Petrescu, F.I. and R.V. Petrescu, 2016c. Dynamic cinematic to a structure $2 \mathrm{R}$. Revista Geintec-Gestao Inovacao E Tecnologias, 6: 3143-3154.
Petrescu, F.I.T. and J.K. Calautit, 2016a. About Nano fusion and dynamic fusion. Am. J. Applied Sci., 13: 261-266. DOI: 10.3844/ajassp.2016.261.266

Petrescu, F.I. and J.K. Calautit, 2016b. About the light dimensions. Am. J. Applied Sci., 13: 321-325. DOI: 10.3844/ajassp.2016.321.325

Petrescu, F.I.T., 2009. New aircraft. Proceedings of the 3rd International Conference on Computational Mechanics, Oct. 29-30, Brasov, Romania.

Petrescu, F.I.T., 2012a. Cold Nuclear Fusion. 1st Edn., Create Space, USA, ISBN-13: 1478234261/9781478234265, pp: 80.

Petrescu, F.I.T., 2012b. Particle Annihilation-A source of renewable energy?

Petrescu, F.I.T., 2012c. Particle annihilation-a source of renewable energy? Infinite Energy.

Petrescu, F.I., 2012d. Basis of Analysis and Optimization of Rigid Memory Systems - Course and Applications. 1st Edn., Create Space publisher, USA, ISBN-13: 978-1-4700-2436-9, pp: 164.

Petrescu, F.I., 2012e. Theory of Mechanisms - Course and Applications. 2nd Edn., Create Space Publisher, USA, ISBN-13: 978-1-4792-9362-9, pp: 284.

Petrescu, R.V.V., R. Aversa, A. Apicella, F. Berto and S. Li et al., 2016a. Ecosphere protection through green energy. Am. J. Applied Sci., 13: 1027-1032. DOI: 10.3844/ajassp.2016.1027.1032.

Petrescu, F.I.T., A. Apicella, R.V.V. Petrescu, S.P. Kozaitis and R.B. Bucinell et al., 2016 b. Environmental protection through nuclear energy. Am. J. Applied Sci., 13: 941-946. DOI: 10.3844/ajassp.2016.941.946

Petrescu, R.V., R. Aversa, B. Akash, R. Bucinell and J. Corchado et al., 2017a. Modern propulsions for aerospace-a review. J. Aircraft Spacecraft Technol., 1: 1-8. DOI: 10.3844/jastsp.2017.1.8

Petrescu, R.V., R. Aversa, B. Akash, R. Bucinell and J. Corchado et al., 2017b. Modern propulsions for aerospace-part II. J. Aircraft Spacecraft Technol., 1: 9-17. DOI: $10.3844 /$ jastsp.2017.9.17

Petrescu, R.V., R. Aversa, B. Akash, R. Bucinell and J. Corchado et al., 2017c. History of aviation-a short review. J. Aircraft Spacecraft Technol., 1: 30-49. DOI: 10.3844 /jastsp.2017.30.49

Petrescu, R.V., R. Aversa, B. Akash, R. Bucinell and J. Corchado et al., 2017d. Lockheed martin-a short review. J. Aircraft Spacecraft Technol., 1: 50-68. DOI: 10.3844 /jastsp.2017.50.68

Petrescu, R.V., R. Aversa, B. Akash, J. Corchado and F. Berto et al., 2017e. Our universe. J. Aircraft Spacecraft Technol., 1: 69-79. DOI: 10.3844 /jastsp.2017.69.79

Petrescu, R.V., R. Aversa, B. Akash, J. Corchado and F. Berto et al., 2017f. What is a UFO? J. Aircraft Spacecraft Technol., 1: 80-90.

DOI: $10.3844 /$ jastsp.2017.80.90 
Petrescu, R.V., R. Aversa, B. Akash, J. Corchado and F. Berto et al., 2017g. About bell helicopter FCX-001 concept aircraft-a short review. J. Aircraft Spacecraft Technol., 1: 91-96.

DOI: 10.3844 jastsp.2017.91.96

Petrescu, R.V., R. Aversa, B. Akash, J. Corchado and F. Berto et al., 2017h. Home at airbus. J. Aircraft Spacecraft Technol., 1: 97-118. DOI: $10.3844 /$ jastsp.2017.97.118

Petrescu, R.V., R. Aversa, B. Akash, J. Corchado and F. Berto et al., 2017i. Airlander. J. Aircraft Spacecraft Technol., 1: 119-148. DOI: $10.3844 /$ jastsp.2017.119.148

Petrescu, R.V., R. Aversa, B. Akash, J. Corchado and F. Berto et al., 2017j. When boeing is dreaming-a review. J. Aircraft Spacecraft Technol., 1: 149-161. DOI: $10.3844 /$ jastsp.2017.149.161

Petrescu, R.V., R. Aversa, B. Akash, J. Corchado and F. Berto et al., 2017k. About Northrop Grumman. J. Aircraft Spacecraft Technol., 1: 162-185. DOI: $10.3844 /$ jastsp.2017.162.185

Petrescu, R.V., R. Aversa, B. Akash, J. Corchado and F. Berto et al., 20171. Some special aircraft. J. Aircraft Spacecraft Technol., 1: 186-203. DOI: $10.3844 /$ jastsp.2017.186.203

Petrescu, R.V., R. Aversa, B. Akash, J. Corchado and F. Berto et al., 2017m. About helicopters. J. Aircraft Spacecraft Technol., 1: 204-223. DOI: $10.3844 /$ jastsp.2017.204.223

Petrescu, R.V., R. Aversa, B. Akash, F. Berto and A. Apicella et al., 2017n. The modern flight. J. Aircraft Spacecraft Technol.

Petrescu, R.V., R. Aversa, B. Akash, F. Berto and A. Apicella et al., 2017o. Sustainable energy for aerospace vessels. J. Aircraft Spacecraft Technol.
Petrescu, R.V., R. Aversa, B. Akash, F. Berto and A. Apicella et al., 2017p. Unmanned helicopters. J. Aircraft Spacecraft Technol.

Petrescu, R.V., R. Aversa, B. Akash, F. Berto and A. Apicella et al., 2017q. Project HARP. J. Aircraft Spacecraft Technol.

Popescu, I., 1977. Design of planar mechanisms. Scrisul Românesc Publishing House of Craiova.

Rehwald, W., K. Luck, 2000. Kosim Koppelgetriebesimulation. Fortschritt Berichte VDI, Reihe 1, Nr. 332. VDI Verlag, Dusseldorf.

Rehwald, W. and K. Luck, 2001. Betrachtungen zur zahl der koppelgetribetypen. Wissenschaftliche Zeitschrift der 50: 107-115.

Stoica, I.A., 1977. Gear wheel interference. 1st Edn., DACIA Publishing House, Cluj-Napoca.

Şaskin, A.G., 1971. Zubciato rîciajnîe mehanizmî. Izd. Maşinostroenie, Moskva.

Şaskin, A.G., 1963. Sintezu zubciato - rîciajnîh mehanizmov $\mathrm{s}$ vâstoem. Teoria maşin I mehanizmov, 94-95: 88-110.

Tutunaru, D., 1969. Rectangular and inverse planar mechanisms. 1st Edn., Technical Publishing House, Bucharest.

Watt steam engine, From Wikipedia, the free encyclopedia.

https://en.wikipedia.org/wiki/Watt_steam_engine

\section{Source of Figures}

Petrescu and Petrescu, 2011c. 